\title{
Pharmacists' Knowledge, Perceptions, and Practices Regarding Herbal Medicine
}

Ashlyn Carr, PharmD; Catherine Santanello, PhD

Southern Illinois University Edwardsville

\begin{abstract}
Introduction: With the increase of herbal medicine sales and a lack of reliable information available to consumers, it is important for pharmacists to be knowledgeable about these products and have the ability to effectively counsel on their uses and risks. The purpose of this study was to: 1) assess community pharmacists' knowledge, perceptions, and practices regarding herbal medicines, 2) understand the impact pharmacists may have on their patients' herbal medicine use, and 3) gauge what practices could be improved. Methods: An anonymous survey was distributed to community pharmacists through email, social media, and in-person at local pharmacies. The survey consisted of general background questions, questions assessing perceptions and practices regarding herbal medicine, and a ten-question true/false quiz to assess knowledge. Survey data was collected and assessed using Qualtrics and Excel. Results: Of the 127 community pharmacists who completed the survey, only 34\% were confident in their ability to effectively counsel patients on herbal medicines. Approximately 50\% of pharmacists reported never or rarely asking patients about herbal medicine use and $80 \%$ reported never or rarely documenting herbal medicine use. Only $25 \%$ of pharmacists reported that they always discuss side effects and 19\% reported that they always discuss herb-drug interactions when patients are using herbal medicines. The average quiz score assessing knowledge of herbal medicines was 6.06 out of 10 .

Conclusions: It is important for community pharmacists to be knowledgeable about herbal medicines and prepared to educate patients to ensure safe medication use. Pharmacists need to acknowledge the use of herbal medicine in their patients and always discuss potential side effects and herb-drug interactions. It is also important that pharmacists know where they can find reliable information on herbal medicines and use evidence-based resources when possible.
\end{abstract}

Keywords: Herbal medicine, community pharmacy, pharmacists

\section{Introduction}

Plants have been used as medicine since ancient times, and we have relied on plants to formulate many of the drugs we use today. ${ }^{1}$ Pharmacognosy, the study of crude drugs of plant and animal origin, incorporates the quality control and authentication of such herbal medicines. ${ }^{2}$ An herbal medicine is a product made from a plant or plant part that is used to maintain or improve health. ${ }^{3}$ Herbs are classified as dietary supplements under the Dietary Supplement Health and Education Act (DSHEA) of $1994 .{ }^{1}$ Herbal medicines are often considered safe by consumers due to their natural composition, but this may not always be the case, due to the nature of their regulation. Under the DSHEA, herbal medicines are not required to demonstrate safety or efficacy before marketing. Therefore, the consistency and safety of over-thecounter (OTC) herbal medicine products are often unreliable. Additionally, contaminants and herb-drug interactions can lead to unexpected side effects. ${ }^{1}$ In particular, herbal medicines can affect cytochrome P450 (CYP) enzymes, Pglycoprotein, and other metabolic enzymes/drug transporters, which can alter the efficacy and safety of prescription medications and other drugs. ${ }^{4}$ Furthermore, adequate research regarding the safety and efficacy of herbal medicine is lacking. Some commonly used herbs, such as St. John's wort

Corresponding author: Catherine Santanello, PhD

Southern Illinois University Edwardsville

Email: csantan@siue.edu and gingko biloba, have scientific evidence suggesting efficacy for certain indications, but studies of herbal medicines often have poor methodologies and conflicting results. Understanding proper dosing and administration is imperative for the safety and efficacy of all drugs, including herbal medicine, particularly since significant concerns regarding inconsistencies with product ingredients and herb-drug interactions have been noted in the medical literature..$^{5}$ This lack of knowledge and evidence may lead health care professionals to be uncertain of the role herbal medicine should play in modern health care approaches. ${ }^{1}$

Although controversy exists among health care professionals, the use of herbal medicine has been on the rise for many years. Herbal supplement sales in the United States have been increasing since 2004 , with an estimated total of $\$ 8.085$ billion sold in 2017, amounting to an $8.5 \%$ increase from $2016 .{ }^{6}$ Some of the top-selling herbal supplements in supermarkets and pharmacies were echinacea, cranberry, turmeric, green tea, ginger, and saw palmetto. ${ }^{6}$ According to the most recent National Health Interview Survey (2012) on the use of complementary health approaches in the United States, nearly $18 \%$ of the population used natural products, including herbal medicine and other non-vitamin, non-mineral supplements. ${ }^{7}$ Individuals with multiple chronic diseases reported a slightly higher frequency (22\%) of natural product use. ${ }^{8}$ Rashrash et al. found that $35 \%$ of adults in the United States used herbal medicine in 2015 , with an average of 2.6 herbal supplements being used. ${ }^{9}$ They also found higher percentages of herbal medicine use in patients with medical conditions such as 
diabetes, heart disease, and arthritis, and that approximately $65 \%$ of the population using herbal medicine was concurrently using prescription or other OTC medications. Although the results of this study were valuable, the study sample was predominantly composed of white women with a college education, which limits generalizability. ${ }^{9}$

Due to increasing demand and the risks of patients using herbal medicine concurrently with conventional medicine, a pharmacist should understand the importance of their role with regards to herbal medicine. According to the World Health Organization, the most accessible health professionals to the public are community pharmacists, also known as retail pharmacists. ${ }^{10}$ These pharmacists have the duty of supplying prescription and non-prescription medications safely, as well as providing appropriate counseling at the time of dispensing. ${ }^{10}$ While pharmacists learn about conventional medications extensively during pharmacy school, courses focusing on herbal medicines are often lacking. Pharmacognosy was formerly a course taught in schools of pharmacy in the United States, but while it may still be present in various forms (e.g., drug discovery), it is usually lacking in curricula as a stand-alone course. ${ }^{2}$ It is evident that the role of a pharmacist regarding herbal medicine is not clearly defined, but several major responsibilities have been suggested in past literature. Specifically, community pharmacists should: acknowledge the use of herbal medicines in their patients; be knowledgeable about herbal medicine; ensure safe and appropriate use of herbal medicine; document the use of herbal medicine by patients; report adverse drug reactions related to herbal medicines; appropriately educate about herbal medicines; and, collaborate with other health care professionals when possible. ${ }^{11}$

While these responsibilities seem appropriate and achievable, there is little research assessing how community pharmacists incorporate herbal medicine into their practice, and which of the aforementioned responsibilities are being followed. The present study focused on community pharmacists due to their accessibility to the public and the availability to purchase herbal medicines over the counter in many community pharmacies. The goal of this study was to learn how community pharmacists perceive herbal medicine, as well as assess their current knowledge of and practices utilizing herbal medicine, to ultimately understand the impact community pharmacists may have on the safe and appropriate use of herbal medicines and gauge what practices could be improved.

\section{Methods}

This was a descriptive study that surveyed community pharmacists. Participants were included in this study if they were a practicing community pharmacist in the United States. An anonymous survey was created using the online platform Qualtrics. The study was granted exemption by the Southern Illinois University Edwardsville (SIUE) Institutional Review Board (IRB). After approval, the survey was distributed to pharmacists through social media posts, delivery to local pharmacies, and by email to all SIUE School of Pharmacy alumni. All surveys were recorded through the Qualtrics survey platform. Surveys delivered in person were picked up at a later date and responses were entered into the online Qualtrics survey by the authors. Due to the methods of distribution, an exact sample size was not obtained, but an estimated 800 pharmacists were provided access to the survey. Data was collected for four weeks during January of 2019. The survey consisted of seven general background questions, seventeen questions assessing perceptions and practices regarding herbal medicine, and a ten-question true/false quiz to assess knowledge. See Tables 1, 2, and 4 for survey questions. The quiz questions focused primarily on commonly used herbal medicines, with two questions about herbal medicine regulation. No validated questionnaire was utilized to prepare the survey, but the questionnaire was similar in format to a survey provided to pharmacists in $2000 .{ }^{12}$ Participants were instructed to choose "unsure" on the quiz questions if they did not know the answer to prevent correct guesses, which would skew the data. Data was collected and assessed using Qualtrics and Excel. Mean and median were used to describe continuous and ordinal data. Questions using the scales of "never" to "always" and "strongly disagree" to "strongly agree" were evaluated using numbers one through five to determine median (never $=1$ to always $=5$, strongly disagree $=1$ to strongly agree $=5$ ).

\section{Results}

A total of 156 surveys were completed, with 29 surveys excluded due to the participants working in settings other than community pharmacies. Based on the estimation of 800 pharmacists who received the survey, there was a response rate of nearly $16 \%$. Of the remaining 127 pharmacists, $83 \%$ worked in chain pharmacies, $13 \%$ worked in independent pharmacies, and $3 \%$ worked in other settings, including specialty and hospital outpatient pharmacies. The majority of pharmacists were in the age range of 25 to 35 years (77\%), with 1 to 5 years of experience as a practicing pharmacist (66\%), and many had very little or no prior herbal medicine education (Table 1). Over half (55\%) of the pharmacists did not have or were unsure if they had access to an evidence-based herbal medicine resource in their pharmacy, and almost all the pharmacists (90\%) worked in pharmacies with herbal medicine available to purchase over the counter. Complete background characteristics are shown in Table 1. 


\begin{tabular}{|c|c|c|}
\hline \multicolumn{3}{|c|}{ Table 1: Background Characteristics } \\
\hline & Response & $\mathrm{n}(\%)$ \\
\hline \multirow[t]{5}{*}{ Age } & $20-24$ & $4(3.15)$ \\
\hline & $25-34$ & $98(77.17)$ \\
\hline & $35-44$ & $15(11.81)$ \\
\hline & $45-54$ & $7(5.51)$ \\
\hline & $55-64$ & $3(2.36)$ \\
\hline \multirow[t]{4}{*}{ How long have you been a practicing pharmacist? } & $1-5$ years & $84(66.14)$ \\
\hline & $6-10$ years & $32(25.20)$ \\
\hline & $11-20$ years & $3(2.36)$ \\
\hline & $>20$ years & $8(6.30)$ \\
\hline \multirow{3}{*}{$\begin{array}{l}\text { Did you have any courses during school that } \\
\text { focused on herbal medicine? }\end{array}$} & Yes & $27(21.26)$ \\
\hline & No & $43(33.86)$ \\
\hline & Very little & $57(44.88)$ \\
\hline \multirow{3}{*}{$\begin{array}{l}\text { Have you completed any herbal medicine } \\
\text { continuing education? }\end{array}$} & Yes & $25(19.69)$ \\
\hline & No & $60(47.24)$ \\
\hline & Very little & $42(33.07)$ \\
\hline \multirow{3}{*}{$\begin{array}{l}\text { Do you have access to an evidence-based herbal } \\
\text { medicine resource at your pharmacy? }\end{array}$} & Yes & $57(44.88)$ \\
\hline & No & $40(31.50)$ \\
\hline & Unknown & $30(23.62)$ \\
\hline \multirow{2}{*}{$\begin{array}{l}\text { Do you have herbal medicines available to } \\
\text { purchase in your pharmacy? }\end{array}$} & Yes & $114(89.76)$ \\
\hline & No & $13(10.24)$ \\
\hline \multirow[t]{3}{*}{ What is your practice setting? } & Chain & $106(83.46)$ \\
\hline & Independent & 17 (13.39) \\
\hline & Other & $4(3.15)$ \\
\hline
\end{tabular}

\section{Practices}

Over half (56\%) of the pharmacists reported that patients ask them questions regarding herbal medicines occasionally, while $29 \%$ reported frequently. Many pharmacists reported rarely or occasionally using evidence-based resources to find information regarding herbal medicine $(64 \%$, median $=3)$. The median response to the questions including frequency of asking patients about herbal medicine use and recording the use of herbal medicines was two (rarely), with $37 \%$ of pharmacists rarely asking patients about herbal medicine use and $50 \%$ of pharmacists never recording the use of herbal medicines in a patient's profile. Many pharmacists reported rarely or occasionally recommending that patients use herbal medicine $(74 \%$, median $=2$ ), rarely or occasionally recommending against patients' use of herbal medicine $65 \%$, median $=3$ ), and frequently or always recommending that patients talk with their primary care physician before initiating any herbal medicine $(72 \%$, median $=4)$. The majority of pharmacists reported occasionally or frequently discussing potential side effects (64\%) and herb-drug interactions (66\%) when a patient purchases or inquires about an herbal medicine, and both responses had a median of four (frequently). All frequencies of pharmacists' herbal medicine practices are shown in Table 2. The total number of responses for six of the statements is 126 , as one participant did not respond to these statements. 
Table 2: Pharmacists' herbal medicine practices.

Please indicate how often you experience the following statements using the scale below:

\begin{tabular}{|c|c|c|c|c|c|c|c|}
\hline & Never & Rarely & Occasionally & Frequently & Always & Total $(n)$ & Median \\
\hline $\begin{array}{l}\text { Patients ask questions } \\
\text { regarding herbal medicine. }\end{array}$ & $\begin{array}{c}1 \\
0.79 \%\end{array}$ & $\begin{array}{c}14 \\
11.02 \%\end{array}$ & $\begin{array}{c}71 \\
55.91 \%\end{array}$ & $\begin{array}{c}37 \\
29.13 \%\end{array}$ & $\begin{array}{c}4 \\
3.15 \%\end{array}$ & 127 & 3 \\
\hline $\begin{array}{l}\text { I ask patients about any herbal } \\
\text { medicine use. }\end{array}$ & $\begin{array}{c}17 \\
13.39 \%\end{array}$ & $\begin{array}{c}47 \\
37.01 \%\end{array}$ & $\begin{array}{c}37 \\
29.13 \%\end{array}$ & $\begin{array}{c}23 \\
18.11 \%\end{array}$ & $\begin{array}{c}3 \\
2.36 \%\end{array}$ & 127 & 2 \\
\hline $\begin{array}{l}\text { I record the use of herbal } \\
\text { medicine in a patient's profile. }\end{array}$ & $\begin{array}{c}63 \\
49.61 \% \\
\end{array}$ & $\begin{array}{c}40 \\
31.50 \% \\
\end{array}$ & $\begin{array}{c}14 \\
11.02 \% \\
\end{array}$ & $\begin{array}{c}4 \\
3.15 \% \\
\end{array}$ & $\begin{array}{c}6 \\
4.72 \% \\
\end{array}$ & 127 & 2 \\
\hline $\begin{array}{l}\text { I strive to review/learn more } \\
\text { information about herbal } \\
\text { medicine. }\end{array}$ & $\begin{array}{c}9 \\
7.09 \%\end{array}$ & $\begin{array}{c}37 \\
29.13 \%\end{array}$ & $\begin{array}{c}61 \\
48.03 \%\end{array}$ & $\begin{array}{c}14 \\
11.02 \%\end{array}$ & $\begin{array}{c}6 \\
4.72 \%\end{array}$ & 127 & 3 \\
\hline $\begin{array}{l}\text { I use evidence-based resources } \\
\text { to find information regarding } \\
\text { herbal medicine. }\end{array}$ & $\begin{array}{c}9 \\
7.14 \%\end{array}$ & $\begin{array}{c}30 \\
23.81 \%\end{array}$ & $\begin{array}{c}51 \\
40.48 \%\end{array}$ & $\begin{array}{c}22 \\
17.46 \%\end{array}$ & $\begin{array}{c}14 \\
11.11 \%\end{array}$ & 126 & 3 \\
\hline $\begin{array}{l}\text { I recommend that patients use } \\
\text { herbal medicine. }\end{array}$ & $\begin{array}{c}30 \\
23.81 \%\end{array}$ & $\begin{array}{c}57 \\
45.24 \%\end{array}$ & $\begin{array}{c}36 \\
28.57 \%\end{array}$ & $\begin{array}{c}3 \\
2.38 \%\end{array}$ & $\begin{array}{c}0 \\
0.00 \%\end{array}$ & 126 & 2 \\
\hline $\begin{array}{l}\text { I recommend against patients' } \\
\text { use of herbal medicine. }\end{array}$ & $\begin{array}{c}18 \\
14.29 \% \\
\end{array}$ & $\begin{array}{c}25 \\
19.84 \% \\
\end{array}$ & $\begin{array}{c}57 \\
45.24 \% \\
\end{array}$ & $\begin{array}{c}22 \\
17.46 \% \\
\end{array}$ & $\begin{array}{c}4 \\
3.17 \% \\
\end{array}$ & 126 & 3 \\
\hline $\begin{array}{l}\text { I recommend that patients talk } \\
\text { with their primary care } \\
\text { physician before initiating any } \\
\text { herbal medicine treatments. }\end{array}$ & $\begin{array}{c}1 \\
0.79 \%\end{array}$ & $\begin{array}{c}10 \\
7.94 \%\end{array}$ & $\begin{array}{c}24 \\
19.05 \%\end{array}$ & $\begin{array}{c}48 \\
38.10 \%\end{array}$ & $\begin{array}{c}43 \\
34.13 \%\end{array}$ & 126 & 4 \\
\hline $\begin{array}{l}\text { I discuss herb-drug interactions } \\
\text { when a person purchases or } \\
\text { inquires about an herbal } \\
\text { medicine. }\end{array}$ & $\begin{array}{c}2 \\
1.59 \%\end{array}$ & $\begin{array}{c}11 \\
8.73 \%\end{array}$ & $\begin{array}{c}36 \\
28.57 \%\end{array}$ & $\begin{array}{c}46 \\
36.51 \%\end{array}$ & $\begin{array}{c}31 \\
24.60 \%\end{array}$ & 126 & 4 \\
\hline $\begin{array}{l}\text { I discuss potential side effects } \\
\text { when a patient purchases or } \\
\text { inquires about an herbal } \\
\text { medicine. }\end{array}$ & $\begin{array}{c}3 \\
2.38 \%\end{array}$ & $\begin{array}{c}18 \\
14.29 \%\end{array}$ & $\begin{array}{c}39 \\
30.95 \%\end{array}$ & $\begin{array}{c}42 \\
33.33 \%\end{array}$ & $\begin{array}{c}24 \\
19.05 \%\end{array}$ & 126 & 4 \\
\hline
\end{tabular}

\section{Perceptions}

Pharmacists had varying opinions on the general safety of herbal medicine and safety when used concurrently with prescription medications (Table 4), but the majority of pharmacists agreed that herbal medicines can provide beneficial health effects $(69 \%$, median $=4)$. Most pharmacists agreed that it is important to be knowledgeable about herbal medicines as a community pharmacist $(87 \%$, median $=4)$ and that it is their responsibility to provide patients with information about herbal medicine $(79 \%$, median $=4)$. Nearly half $(49 \%)$ of the pharmacists agreed that they were not confident in their ability to provide adequate information about herbal medicine to patients, while $35 \%$ did agree. Of the pharmacists who had completed herbal medicine continuing education (answered yes), 60\% somewhat or strongly agreed that they were confident in their ability to educate, compared to $26 \%$ in the group with very little continuing education, and $28 \%$ in the group with none. Results were similar in the group who had herbal medicine courses during school (Table 3). All frequencies of pharmacists' herbal medicine perceptions are shown in Table 4. 


\begin{tabular}{|c|c|c|c|c|c|c|}
\hline & & \multicolumn{5}{|c|}{$\begin{array}{l}\text { I am confident in my ability to provide adequate } \\
\text { information about herbal medicine to patients. }\end{array}$} \\
\hline & & $\begin{array}{c}\text { Strongly } \\
\text { agree }\end{array}$ & $\begin{array}{c}\text { Somewhat } \\
\text { agree }\end{array}$ & $\begin{array}{l}\text { Neither agree } \\
\text { nor disagree }\end{array}$ & $\begin{array}{c}\text { Somewhat } \\
\text { disagree }\end{array}$ & $\begin{array}{l}\text { Strongly } \\
\text { disagree }\end{array}$ \\
\hline \multirow{3}{*}{$\begin{array}{l}\text { Have you completed any } \\
\text { herbal medicine } \\
\text { continuing education? }\end{array}$} & Yes & $\begin{array}{c}5 \\
20.00 \%\end{array}$ & $\begin{array}{c}10 \\
40.00 \%\end{array}$ & $\begin{array}{c}5 \\
20.00 \%\end{array}$ & $\begin{array}{c}4 \\
16.00 \%\end{array}$ & $\begin{array}{c}1 \\
4.00 \%\end{array}$ \\
\hline & No & $\begin{array}{c}1 \\
1.67 \% \\
\end{array}$ & $\begin{array}{c}16 \\
26.67 \% \\
\end{array}$ & $\begin{array}{c}10 \\
16.67 \% \\
\end{array}$ & $\begin{array}{c}22 \\
36.67 \% \\
\end{array}$ & $\begin{array}{c}11 \\
18.33 \% \\
\end{array}$ \\
\hline & $\begin{array}{l}\text { Very } \\
\text { little }\end{array}$ & $\begin{array}{c}2 \\
4.76 \% \\
\end{array}$ & $\begin{array}{c}9 \\
21.43 \%\end{array}$ & $\begin{array}{c}7 \\
16.67 \%\end{array}$ & $\begin{array}{c}19 \\
45.24 \% \\
\end{array}$ & $\begin{array}{c}5 \\
11.90 \%\end{array}$ \\
\hline \multirow{3}{*}{$\begin{array}{l}\text { Did you have any } \\
\text { courses during school } \\
\text { that focused on herbal } \\
\text { medicine? }\end{array}$} & Yes & $\begin{array}{c}4 \\
14.81 \% \\
\end{array}$ & $\begin{array}{c}9 \\
33.33 \% \\
\end{array}$ & $\begin{array}{c}7 \\
25.93 \% \\
\end{array}$ & $\begin{array}{c}3 \\
11.11 \%\end{array}$ & $\begin{array}{c}4 \\
14.81 \% \\
\end{array}$ \\
\hline & No & $\begin{array}{c}2 \\
4.65 \% \\
\end{array}$ & $\begin{array}{c}14 \\
32.56 \% \\
\end{array}$ & $\begin{array}{c}6 \\
13.95 \% \\
\end{array}$ & $\begin{array}{c}14 \\
32.56 \% \\
\end{array}$ & $\begin{array}{c}7 \\
16.28 \% \\
\end{array}$ \\
\hline & $\begin{array}{l}\text { Very } \\
\text { little }\end{array}$ & $\begin{array}{c}2 \\
3.51 \%\end{array}$ & $\begin{array}{c}12 \\
21.05 \%\end{array}$ & $\begin{array}{c}9 \\
15.79 \%\end{array}$ & $\begin{array}{c}28 \\
49.12 \%\end{array}$ & $\begin{array}{c}6 \\
10.53 \%\end{array}$ \\
\hline
\end{tabular}

\begin{tabular}{|c|c|c|c|c|c|c|c|}
\hline \multicolumn{8}{|c|}{ Please indicate your opinion on the following statements using the scale below: } \\
\hline & $\begin{array}{l}\text { Strongly } \\
\text { disagree }\end{array}$ & $\begin{array}{c}\text { Somewhat } \\
\text { disagree }\end{array}$ & $\begin{array}{l}\text { Neither } \\
\text { agree nor } \\
\text { disagree }\end{array}$ & $\begin{array}{l}\text { Somewhat } \\
\text { agree }\end{array}$ & $\begin{array}{l}\text { Strongly } \\
\text { agree }\end{array}$ & $\begin{array}{c}\text { Total } \\
(n)\end{array}$ & Median \\
\hline $\begin{array}{l}\text { I know where I can find } \\
\text { reliable information about } \\
\text { herbal medicines. }\end{array}$ & $\begin{array}{c}10 \\
7.87 \%\end{array}$ & $\begin{array}{c}19 \\
14.96 \%\end{array}$ & $\begin{array}{c}15 \\
11.81 \%\end{array}$ & $\begin{array}{c}57 \\
44.88 \%\end{array}$ & $\begin{array}{c}26 \\
20.47 \%\end{array}$ & 127 & 4 \\
\hline $\begin{array}{l}\text { Herbal medicines are } \\
\text { generally safe to use. }\end{array}$ & $\begin{array}{c}7 \\
5.51 \%\end{array}$ & $\begin{array}{c}38 \\
29.92 \%\end{array}$ & $\begin{array}{c}48 \\
37.80 \%\end{array}$ & $\begin{array}{c}33 \\
25.98 \%\end{array}$ & $\begin{array}{c}1 \\
0.79 \%\end{array}$ & 127 & 3 \\
\hline $\begin{array}{l}\text { Herbal medicines are safe to } \\
\text { use with other prescription } \\
\text { medications. }\end{array}$ & $\begin{array}{c}12 \\
9.45 \%\end{array}$ & $\begin{array}{c}56 \\
44.09 \%\end{array}$ & $\begin{array}{c}34 \\
26.77 \%\end{array}$ & $\begin{array}{c}25 \\
19.69 \%\end{array}$ & $\begin{array}{c}0 \\
0.00 \%\end{array}$ & 127 & 2 \\
\hline $\begin{array}{l}\text { Herbal medicines can } \\
\text { provide beneficial health } \\
\text { effects. }\end{array}$ & $\begin{array}{c}5 \\
3.94 \%\end{array}$ & $\begin{array}{c}7 \\
5.51 \%\end{array}$ & $\begin{array}{c}28 \\
22.05 \%\end{array}$ & $\begin{array}{c}75 \\
59.06 \%\end{array}$ & $\begin{array}{c}12 \\
9.45 \%\end{array}$ & 127 & 4 \\
\hline $\begin{array}{l}\text { I am confident in my ability } \\
\text { to provide adequate } \\
\text { information about herbal } \\
\text { medicine to patients. }\end{array}$ & $\begin{array}{c}17 \\
13.39 \%\end{array}$ & $\begin{array}{c}45 \\
35.43 \%\end{array}$ & $\begin{array}{c}22 \\
17.32 \%\end{array}$ & $\begin{array}{c}35 \\
27.56 \%\end{array}$ & $\begin{array}{c}8 \\
6.30 \%\end{array}$ & 127 & 3 \\
\hline $\begin{array}{l}\text { It is important to be } \\
\text { knowledgeable about herbal } \\
\text { medicines as a community } \\
\text { pharmacist. }\end{array}$ & $\begin{array}{c}2 \\
1.57 \%\end{array}$ & $\begin{array}{c}5 \\
3.94 \%\end{array}$ & $\begin{array}{c}9 \\
7.09 \%\end{array}$ & $\begin{array}{c}57 \\
44.88 \%\end{array}$ & $\begin{array}{c}54 \\
42.52 \%\end{array}$ & 127 & 4 \\
\hline $\begin{array}{l}\text { As a pharmacist, it is my } \\
\text { responsibility to provide } \\
\text { patients with information } \\
\text { about herbal medicines. }\end{array}$ & $\begin{array}{c}2 \\
1.57 \%\end{array}$ & $\begin{array}{c}14 \\
11.02 \%\end{array}$ & $\begin{array}{c}10 \\
7.87 \%\end{array}$ & $\begin{array}{c}56 \\
44.09 \%\end{array}$ & $\begin{array}{c}45 \\
35.43 \%\end{array}$ & 127 & 4 \\
\hline
\end{tabular}




\section{Knowledge}

With respect to the quiz assessing knowledge of herbal medicines, the mean score was 6.06 out of 10 with a standard deviation of 1.93. Pharmacists with prior herbal medicine education had slightly higher mean quiz scores than those with no herbal medicine education (Figure 1). Most pharmacists answered correctly when asked about the regulation and marketing of herbal medicines. Other questions with greater than $50 \%$ of the responses answered correctly included questions regarding St. John's wort, garlic, gingko biloba, and ginger. Questions regarding echinacea, ginseng, chamomile, and saw palmetto had correct responses ranging from $18 \%$ to 43\%. Complete quiz results are shown in Table 5.

Figure 1: Mean scores of pharmacists with prior herbal medicine education.

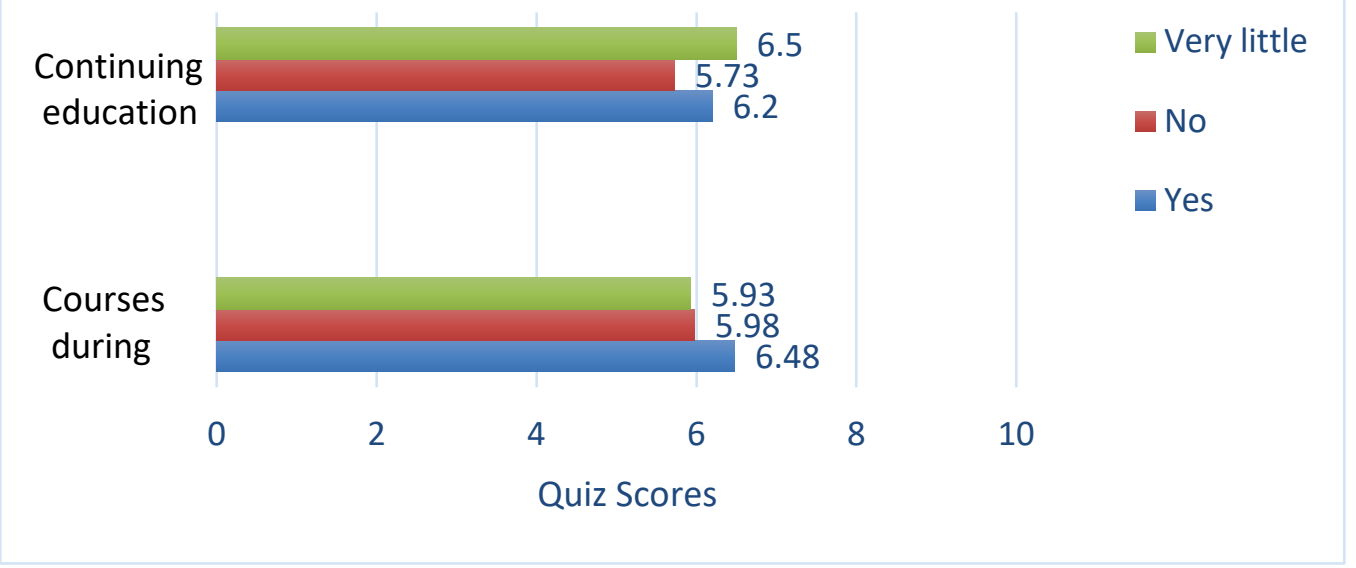

\begin{tabular}{|c|c|c|c|}
\hline & True & False & Unsure \\
\hline $\begin{array}{l}\text { Herbal products are regulated by the FDA under the Federal Food, Drug, and } \\
\text { Cosmetic Act. }\end{array}$ & $\begin{array}{c}9 \\
7.09 \%\end{array}$ & $\begin{array}{c}106^{*} \\
83.46 \%\end{array}$ & $\begin{array}{c}12 \\
9.45 \%\end{array}$ \\
\hline $\begin{array}{l}\text { Safety and efficacy of herbal products must be } \\
\text { proven before they are marketed. }\end{array}$ & $\begin{array}{c}6 \\
4.72 \%\end{array}$ & $\begin{array}{c}113^{*} \\
88.98 \%\end{array}$ & $\begin{array}{c}8 \\
6.30 \%\end{array}$ \\
\hline St. John's wort is commonly used for mild to moderate depression. & $\begin{array}{c}115^{*} \\
90.55 \%\end{array}$ & $\begin{array}{c}5 \\
3.94 \% \\
\end{array}$ & $\begin{array}{c}7 \\
5.51 \% \\
\end{array}$ \\
\hline Echinacea is a safe treatment for patients with autoimmune diseases. & $\begin{array}{c}12 \\
9.45 \%\end{array}$ & $\begin{array}{c}45^{*} \\
35.43 \% \\
\end{array}$ & $\begin{array}{c}70 \\
55.12 \%\end{array}$ \\
\hline Garlic can increase the risk of bleeding. & $\begin{array}{c}95^{*} \\
74.80 \%\end{array}$ & $\begin{array}{c}5 \\
3.94 \%\end{array}$ & $\begin{array}{c}27 \\
21.26 \%\end{array}$ \\
\hline Ginkgo biloba is commonly used for dementia. & $\begin{array}{c}93^{*} \\
73.23 \%\end{array}$ & $\begin{array}{c}10 \\
7.87 \%\end{array}$ & $\begin{array}{c}24 \\
18.90 \%\end{array}$ \\
\hline Ginseng is commonly used for the treatment/prevention of the common cold. & $\begin{array}{c}48 \\
37.80 \%\end{array}$ & $\begin{array}{c}32 * \\
25.20 \%\end{array}$ & $\begin{array}{c}47 \\
37.01 \%\end{array}$ \\
\hline Saw palmetto is contraindicated in men with benign prostatic hyperplasia. & $\begin{array}{c}35 \\
27.56 \%\end{array}$ & $\begin{array}{c}55^{*} \\
43.31 \%\end{array}$ & $\begin{array}{c}37 \\
29.13 \%\end{array}$ \\
\hline Chamomile is safe for diabetic patients. & $\begin{array}{c}23^{*} \\
18.11 \%\end{array}$ & $\begin{array}{c}8 \\
6.30 \%\end{array}$ & $\begin{array}{c}96 \\
75.59 \%\end{array}$ \\
\hline Ginger is contraindicated in pregnancy. & $\begin{array}{c}4 \\
3.15 \% \\
\end{array}$ & $\begin{array}{c}93^{*} \\
73.23 \%\end{array}$ & $\begin{array}{c}30 \\
23.62 \%\end{array}$ \\
\hline
\end{tabular}




\section{Discussion}

Community pharmacists are the most accessible health care professionals to the public and have the responsibility of supplying prescription and non-prescription medications safely, as well as providing the appropriate counseling at the time of dispensing. ${ }^{10}$ Pharmacists providing herbal medicines should have a professional responsibility to ensure that herbal medicine stocks are from a reputable source, offer advice only if they have suitable training, and recommend remedies only if they are certain of the safety and quality. ${ }^{11}$

Herbal medicine sales are increasing every year ${ }^{6}$, and in accordance with the results of this survey, nearly all community pharmacies had herbal medicine available to purchase over the counter. It was reported that patients in pharmacies occasionally ask their pharmacists about herbal medicine, but it is possible that many who use herbal medicine are not disclosing that information to their pharmacist. It is important that pharmacists are acknowledging their patients' use of herbal medicines and documenting that information, but many pharmacists reported rarely asking patients about herbal medicine use and rarely or never recording the use of herbal medicine in a patient's medication profile. These practices need to be improved, as many herbal medicines can interact with prescription medications and the pharmacist may need to make an intervention to prevent an herb-drug interaction. ${ }^{4}$ Although the median response of questions regarding the frequency of discussing interactions and side effects of herbal medicines was four (frequently), roughly one quarter of participants reported that they always discuss herbdrug interactions or possible side effects when a patient purchases or inquires about an herbal medicine. Since many patients may be unaware of the safety concerns or regulation of herbal medicine, it is vital that pharmacists are always discussing possible interactions and side effects. As a community pharmacist, it may be difficult to find the time to speak with patients about herbal medicine, and documentation of OTC medications may not be a routine task, but these are practices that must be improved to ensure safe medication use. ${ }^{13}$

Along with safety, it is important for pharmacists to ensure appropriate use of herbal medicines. ${ }^{13}$ Approximately $69 \%$ of pharmacists reported never or rarely recommending herbal medicines, and $63 \%$ reported occasionally or frequently recommending against the use of herbal medicines. Pharmacists are likely making these recommendations per safety and efficacy concerns but may also lack the appropriate knowledge to confidently recommend an herbal medicine and provide adequate counseling. Roughly one third of pharmacists reported having confidence in their ability to provide patients with the appropriate information about herbal medicine. Being knowledgeable and having the ability to provide education about herbal medicines are skills necessary for community pharmacists, just as they are necessary with other OTC products. ${ }^{9}$ Most pharmacists agreed that as a community pharmacist it is important to be knowledgeable about herbal medicine and that is it their responsibility to use that knowledge to educate patients who are using herbal medicine. Most pharmacists had very little to no prior education on herbal medicine. Pharmacists who did have prior herbal medicine education, in school or from continuing education, were more likely to feel confident in their ability to educate patients about herbal medicine (Table 3). Although increased confidence was associated with prior education, quiz scores were only slightly higher in pharmacists with prior education compared to those with none (Figure 1). These results were in contrast to the results from a prior study of pharmacists' knowledge of herbal medicine. Chang et al. (2000) found that pharmacists in North Carolina and Virginia with prior continuing education on herbal medicine had significantly higher scores on a fifteen-question quiz assessing knowledge of herbal medicine. ${ }^{12}$ The average quiz score in the Chang et al. study was 6.3 out of 15 (42\%). Quiz scores from this study were higher with a mean of 6.06 out of 10 (60.6\%), but a conclusive comparison cannot be made as the two quizzes differed in factors such as content and location of respondents.

The quiz used in this study was similar to the quiz written by Chang et al. but was shorter by five questions and contained two questions regarding regulation of herbal medicines. As in Chang et al., pharmacists were more likely to answer correctly about uses of herbal medicines, and less likely to answer correctly about their cautions and adverse effects. ${ }^{12}$ In the present study, almost all the pharmacists answered the two regulation questions correctly, and many pharmacists answered correctly when asked about the uses of St. John's wort and gingko biloba, and safety concerns/contraindications of garlic and ginger. The questions that most pharmacists answered incorrectly included questions regarding the use of ginseng and safety concerns/contraindications of echinacea, chamomile, and saw palmetto (Table 3). Although higher quiz scores were not associated with prior education, the authors still believe that education regarding herbal medicine in school and through continuing education is important for pharmacists and should be a priority, as it is for conventional OTC medications.

The Southern Illinois University Edwardsville School of Pharmacy offers limited educational opportunities on herbal medicines, including an herbal supplement lecture during a mandatory self-care course. There is also an elective course regarding medicinal plants and tropical diseases in which the students experience medicinal plant guided tours in Costa Rica. Schools of pharmacy should consider providing more comprehensive herbal medicine courses to students, as well as implementing a larger focus on pharmacognosy throughout pharmaceutical courses. Along with education, pharmacists should know where to access reliable information about 
herbal medicine. Less than one third of the participants reported frequently or always using evidence-based resources to find information regarding herbal medicine. Since over half of the pharmacists did not have or were unsure if they had access to an evidence-based herbal medicine resource in their pharmacy, and many did not know where they could find reliable information on herbal medicine, this is important information to have. Common online pharmacy resources including Micromedex, Facts and Comparisons, and Lexi-Comp contain evidence-based information on herbal medicines and may be available to community pharmacists paid for by their company. One of the most comprehensive online resources for herbal medicines is Natural Medicines (published by Therapeutic Research Faculty), but it may not be accessible to many pharmacists because it is cost prohibitive. A free resource available to all pharmacists is the National Center for Complementary and Integrative Health's website, but the information available is quite limited compared to the previously mentioned resources. Other free online resources with limited information regarding herbal supplements include the U.S. Food and Drug Administration and National Institutes of Health Office of Dietary Supplements.

\section{Strengths and Limitations}

Strengths of this study included the sample size and the complete anonymity of the survey, which likely improved pharmacists' honesty in their responses. Additionally, the relevance of the topic likely sparked interest in completing the survey since herbal medicine sales are increasing. There were some limitations to this study. One limitation was that the results may not be generalizable to all community pharmacists in the Unites States. Most of the surveys were completed by pharmacists who only had one to five years of experience, and since the survey was distributed through social media, emailed to SIUE School of Pharmacy alumni, and delivered to local pharmacies, there was likely a high proportion of SIUE alumni respondents and pharmacists residing in the local region. These factors may have resulted in survey bias. Additionally, the quiz may not have provided a complete analysis of pharmacists' knowledge of herbal medicines. It only contained eight questions about specific herbal medicines and two questions about regulations. To improve response rates, the survey was kept to a short length, but it may have been better to use a slightly longer survey similar to the survey by Chang et al. ${ }^{12}$ to more effectively compare quiz results. Lastly, the option "very little" in the survey questions regarding prior herbal medicine education (Table 1) may have been confusing for survey participants since it did not have a definitive quantity. This option was offered because some schools, such as SIUE, offer herbal medicine electives or include herbal medicine as a minor topic in non-elective courses.

\section{Conclusion}

Due to increasing sales and the prominent availability of herbal medicine in most pharmacies, it is imperative that community pharmacists are knowledgeable about herbal medicines and prepared to educate their patients. Community pharmacists can play an important role in ensuring medication safety by always discussing possible herb-drug interactions, side effects, and safety concerns of herbal medicines with patients. Pharmacists can improve their accountability by asking patients about herbal medicine use and documenting their response. The percentage of pharmacists educated on herbal medicines is generally quite low and their level of education is directly related to their confidence in providing adequate herbal medicine information to patients. Herbal medicine knowledge and the ability to counsel patients should be a necessity to pharmacists, just as it is with conventional OTC products. The authors believe it would be greatly beneficial for schools of pharmacy to offer herbal medicine courses, including pharmacognosy, in their curricula due to the reemergence of interest in these products. Lastly, since the quality of information available about herbal medicine varies widely, evidence-based resources should ideally be used. It is the authors' hope that pharmacists reading this study will now be informed of resources available to them and more inclined to use these resources to improve their practices.

Acknowledgement: Thank you to all of the pharmacists who made this study successful by taking time to participate in the survey.

\section{References}

1. Bent S. Herbal medicine in the United States: review of efficacy, safety, and regulation: grand rounds at University of California, San Francisco Medical Center. J Gen Intern Med. 2008 Jun;23(6):854-9. doi: 10.1007/s11606008-0632-y. Epub 2008 Apr 16. Review.

2. Sarker, SD. Pharmacognosy in Modern Pharmacy Curricula. Pharmacognosy Magazine. 2012 Apr-Jun;8(30):91-92.

3. National Institutes of Health Office of Dietary Supplements [Internet]. Botanical Dietary Supplements: Background Information. 2011 [cited 2019 Jan 10]. Available from: https://ods.od.nih.gov/factsheets/BotanicalBac kground-HealthProfessional/.

4. Asher GN, Corbett AH, Hawke RL. Common Herbal Dietary Supplement-Drug Interactions. Am Fam Physician. 2017 Jul 15;96(2):101-107. Review.

5. Glisson JK, Rogers HE, Abourashed EA, Ogletree $R$, Hufford CD, Khan I. Clinic at the Health Food Store? Employee Recommendations and Product Analysis. Pharmacotherapy 2003;23(1):64-72. 
6. Smith T, Kawa K, Eckl V, Morton C, Stredney R. Herbal Supplement Sales in US Increased 8.5\% in 2017, Topping \$8

Billion. HerbalGram. 2018;119:62-71.

7. Clarke TC, Black LI, Stussman BJ, Barnes PM, Nahin RL. Trends in the use of complementary health approaches among adults: United States, 2002-2012. Natl Health Stat Report. 2015 Feb 10;(79):1-16.

8. Falci L, Shi Z, Greenlee H. Multiple Chronic Conditions and Use of Complementary and Alternative Medicine Among US Adults: Results From the 2012 National Health Interview Survey. Prev Chronic Dis. 2016 May 5;13:E61.

9. Rashrash M, Schommer JC, Brown LM.

Prevalence and Predictors of Herbal Medicine Use Among Adults in the United States. J Patient Exp. 2017 Sep;4(3):108-113.

10. World Health Organization. The role of the pharmacist in the health care system [Internet]. Proceedings of WHO conferences; 1988 Dec 12-16; New Delhi, India; 1993 Aug 31-Sep 2; Tokyo, Japan. WHO; 1994 [cited 2019 Jan 10]. p. 10-12. Available from: http://apps.who.int/medicinedocs/en/d/Jh299 5e/1.6.2.html\#Jh2995e.1.6.2.

11. Heinrich M, Barnes J, Gibbons S, Williamson EM. Fundamentals of Pharmacognosy and Phytotherapy, Elsevier Limited, London, England, 2004.

12. Chang ZG, Kennedy DT, Holdford DA, Small RE. Pharmacists' knowledge and attitudes toward herbal medicine. Ann Pharmacother. 2000 Jun;34(6):710-5.

13. Ung COL, Harnett J, Hu H. Community pharmacist's responsibilities with regards to traditional medicine/complementary medicine products: A systematic literature review. Res Social Adm Pharm. 2017 Jul - Aug;13(4):686716. 